University of Nebraska - Lincoln

DigitalCommons@University of Nebraska - Lincoln

Agronomy \& Horticulture -- Faculty Publications

Agronomy and Horticulture Department

June 2002

\title{
Soil Properties as Influenced by Phosphorus- and Nitrogen-Based Manure and Compost Applications
}

\author{
Bahman Eghball \\ University of Nebraska-Lincoln
}

Follow this and additional works at: https://digitalcommons.unl.edu/agronomyfacpub

Part of the Plant Sciences Commons

Eghball, Bahman, "Soil Properties as Influenced by Phosphorus- and Nitrogen-Based Manure and Compost Applications" (2002). Agronomy \& Horticulture -- Faculty Publications. 16.

https://digitalcommons.unl.edu/agronomyfacpub/16

This Article is brought to you for free and open access by the Agronomy and Horticulture Department at DigitalCommons@University of Nebraska - Lincoln. It has been accepted for inclusion in Agronomy \& Horticulture -Faculty Publications by an authorized administrator of DigitalCommons@University of Nebraska - Lincoln. 


\title{
WASTE MANAGEMENT
}

\section{Soil Properties as Influenced by Phosphorus- and Nitrogen-Based Manure and Compost Applications}

\author{
Bahman Eghball*
}

\begin{abstract}
Manure or compost application based on $\mathrm{N}$ needs of corn (Zea mays L.) may result in soil accumulation of $P, N$, and other ions, since the manure or compost $\mathrm{N} / \mathrm{P}$ ratio is usually smaller than the corn N/P uptake ratio. This study was conducted from 1992 to 1996 to evaluate the effects of annual or biennial application of $\mathrm{N}$ - and P-based composted and noncomposted beef cattle (Bos taurus) feedlot manure on soil properties. Fertilized and unfertilized checks were also included. Soil surface $(0-15 \mathrm{~cm}) \mathrm{pH}$ significantly increased with $\mathrm{N}$-based manure (MN) or compost application $(\mathrm{CN})$, but decreased with $\mathrm{NH}_{4}-\mathrm{N}$ fertilizer application as compared with the check. Soil bulk density was unaffected by manure or compost application. After 4 yr of manure and compost applications, soil surface $(0-15 \mathrm{~cm}) \mathrm{C}$ and $\mathbf{N}$ concentrations and quantities were greater for $\mathbf{N}$ - than $\mathbf{P}$-based management systems. About $25 \%$ of applied manure $\mathrm{C}$ and $36 \%$ of applied compost $\mathrm{C}$ remained in the soil after $4 \mathrm{yr}$ of application, indicating greater $\mathrm{C}$ sequestration with composted than noncomposted manure. No significant difference was observed between fertilizer and check plots for soil total $C$ or $N$. Soil properties in the 15- to 30$\mathrm{cm}$ increment were unaffected by the applied treatments except soil electrical conductivity (EC). Residual soil $\mathrm{NO}_{3}$ to a depth of $1.2 \mathrm{~m}$ was greater for inorganic fertilizer than manure and compost treatments in drier years. Soil property changes were greater for the annual or biennial N-based than P-based manure or compost applications, reflecting the differences in application amounts.
\end{abstract}

$\mathrm{B}$ EEF CATTLE FEEDING is concentrated in the Central and Southern Great Plains. At any one time, there are at least 10 million head of beef cattle on feed in the United States (USDA, 1997) generating manure that contains $529900 \mathrm{Mg} \mathrm{N}, 157000 \mathrm{Mg} \mathrm{P}$, and $482000 \mathrm{Mg} \mathrm{K}$ each year, based on manure $\mathrm{N}, \mathrm{P}$, and $\mathrm{K}$ concentrations (Overcash et al., 1983). In addition to nutrients, beef cattle feedlot manure also contains $\approx 15 \% \mathrm{C}$ that can be used to improve soil physical and chemical properties. Carbon in manure is likely to have far greater value than the nutrients it contains if applied to a low organic matter or eroded soil.

Composting manure is a useful method of producing a stabilized product that can be stored or spread with little odor or fly-breeding potential. The other advantages of composting include killing pathogens and weed seeds, and improving handling characteristics of manure by reducing manure volume and weight. However, com-

USDA-ARS, Dep. of Agron. and Hortic., Univ. of Nebraska-Lincoln, Lincoln, NE 68583. Joint contribution of USDA-ARS and Univ. of Nebraska Agric. Res. Div., Lincoln, NE, as paper no. 12996. Received 29 Mar. 2001.*Corresponding author (beghball1@unl.edu).

Published in Agron. J. 94:128-135 (2002). posting has some disadvantages that include nutrient and $\mathrm{C}$ loss during composting, the cost of land, equipment, and labor required for composting, and odor associated with composting.

Manure application in excess of crop requirements can cause a significant buildup of $\mathrm{P}, \mathrm{N}$, and salt in soil. After $18 \mathrm{yr}$ of manure application, surface soil cation exchange capacity, total organic $\mathrm{C}$, and total $\mathrm{N}$ increased with increasing rate of manure application (Gao and Chang, 1996). Schlegel (1992) found that soil P, K, and organic matter increased with increasing rate of composted beef cattle feedlot manure applied from 1987 to 1990 , while increasing rates of synthetic $\mathrm{N}$ fertilizer application decreased soil $\mathrm{P}$ and $\mathrm{K}$, but had no effect on soil organic matter content. In this study, soil nitrate levels were unaffected by compost application but increased with chemical fertilizer application. In another study, eleven annual applications of cattle feedlot manure increased soil organic matter, total $\mathrm{N}, \mathrm{NO}_{3}$, total $\mathrm{P}$, available $\mathrm{P}$, soluble $\mathrm{Na}, \mathrm{Ca}+\mathrm{Mg}, \mathrm{Cl}, \mathrm{SO}_{4}, \mathrm{HCO}_{3}$, and $\mathrm{Zn}$ (Chang et al., 1991). About $1 \mathrm{Mg} \mathrm{ha}^{-1} \mathrm{NO}_{3}-\mathrm{N}$ accumulated at the recommended application rate of $30 \mathrm{Mg} \mathrm{ha}^{-1} \mathrm{yr}^{-1}$ after $11 \mathrm{yr}$ of application. Davis et al. (1997) showed that residual soil $\mathrm{NO}_{3}-\mathrm{N}$ after heavy manure application was greater in heavy-textured soils than sandy soils. Chang and Janzen (1996) found that losses of $\mathrm{N}$ through leaching and volatilization were less for rainfed than irrigated treatments when annual beef cattle feedlot manure was applied. The proportion of manure $\mathrm{N}$ mineralized was independent of manure rate and irrigation, and during $20 \mathrm{yr}$ of manure application, $\approx 56 \%$ of manure $\mathrm{N}$ was mineralized.

Soil $\mathrm{pH}$ may be influenced by manure application. Eghball (1999) found that application of beef cattle feedlot manure or compost increased the soil surface $(0-15 \mathrm{~cm}) \mathrm{pH}$ while $\mathrm{N}$ application as $\mathrm{NH}_{4} \mathrm{NO}_{3}$ significantly reduced the $\mathrm{pH}$ (from 6.4 to 5.6). The increase in soil $\mathrm{pH}$ with manure and compost application was attributed to a beef cattle diet that contains $\approx 15 \mathrm{~g} \mathrm{CaCO}_{3}$ $\mathrm{kg}^{-1}$. Manure and compost effects on soil $\mathrm{pH}$ depends on the initial soil pH level. Chang et al. (1991) reported that the EC and sodium absorption ratio of soil increased and soil $\mathrm{pH}$ decreased with increasing rate of manure application (soil $\mathrm{pH}$ in the $0-15 \mathrm{~cm}$ was 7.8 and manure had a mean $\mathrm{pH}$ of 7.3). In another study, man-

Abbreviations: CN, compost application for corn $\mathrm{N}$ needs; $\mathrm{CP}$, compost for corn P needs; EC, electrical conductivity; $\mathrm{MN}$, manure application for corn $\mathrm{N}$ needs; MN2Y, manure for corn $\mathrm{N}$ needs for $2 \mathrm{yr}$; MP, manure application for corn P needs. 
ure application counteracted the lowering of soil $\mathrm{pH}$ associated with fertilizer application (Magdoff and Amadon, 1980).

Soil organic matter increases with manure application. In a long-term study in Germany, more than 100 yr of manure application increased soil organic matter fractions associated with the fine and medium silt fractions, while clay-associated fragments were higher in the unfertilized treatment (Schulten and Leinweber, 1991). Vitosh et al. (1973) calculated the organic matter content increase of $0.1 \%$ each year in a sandy loam soil with the application of $67.2 \mathrm{Mg} \mathrm{ha}^{-1}$ fresh cattle manure. Cattle feedlot manure application increased total organic $\mathrm{C}$, total $\mathrm{N}$, potentially mineralizable $\mathrm{N}$, soluble $\mathrm{P}$, and soil microbial biomass, compared with soils receiving no manure (Fraser et al., 1988).

Organic matter in manure may decrease the bulk density of the amended soil. Surface $(0-15 \mathrm{~cm})$ soil bulk density decreased from $0.96 \mathrm{Mg} \mathrm{m}^{-3}$ with no manure to $0.78 \mathrm{Mg} \mathrm{m}^{-3}$ with $90 \mathrm{Mg} \mathrm{ha}^{-1}$ (wet weight) manure application (Sommerfeldt and Chang, 1985). The 15- to $30-\mathrm{cm}$ soil bulk density was lowest when manure was plowed under as compared with manure incorporation by rototilling or cultivation.

Manure or compost application to provide for corn $\mathrm{N}$ requirements greatly increases soil levels of $\mathrm{P}$ (Eghball and Power, 1999). This is because the N/P ratios of beef cattle feedlot manure and composted manure are significantly smaller than N/P uptake ratios of most crops. The N/P ratio was 2.6 for feedlot manure and 1.9 for composted manure (Eghball et al., 1997), while N/P grain uptake ratios of winter wheat, corn, and grain sorghum were 4.5, 5.9, and 4.5, respectively (Gilbertson et al., 1979). Manure and compost applications based on nutrient management strategies (i.e., N- or P-based) would reduce the negative agronomic and environmental effects of the usual certain $\mathrm{Mg}$ per hectare application rates. Information on the effects of these manure management strategies is needed, as more states are adopting these approaches. The objective of this study was to evaluate the effects of application frequency and $\mathrm{N}$ and P-based applications of composted and noncomposted manure on soil $\mathrm{C}, \mathrm{N}, \mathrm{NO}_{3}-\mathrm{N}, \mathrm{NH}_{4}-\mathrm{N}, \mathrm{pH}$, and EC levels, and soil bulk density.

\section{MATERIALS AND METHODS}

The experiment was initiated in 1992 on a Sharpsburg silty clay loam soil (fine, smectitic, mesic Typic Argiudolls) under rainfed conditions at the University of Nebraska Agricultural Research Center near Mead, NE. Growing season rainfall (1 May to 15 October) was $773,558,307$, and $425 \mathrm{~mm}$ in 1993 , 1994, 1995, and 1996, respectively. Average rainfall during this period in the last $30 \mathrm{yr}$ was $493 \mathrm{~mm}$. Rainfall from 1 June to 31 August for the above years was 595, 405, 107, and 215 $\mathrm{mm}$, respectively. The plots were irrigated three times in 1995 for a total of $75 \mathrm{~mm}$ during July and August to avoid losing the experiment. The study area had a Bray and Kurtz no. 1 soil P test of $69 \mathrm{mg} \mathrm{kg}^{-1}$, a pH of 6.2, and a soil organic matter content of $31 \mathrm{~g} \mathrm{~kg}^{-1}$ in the top $15 \mathrm{~cm}$.

The experimental design was a randomized complete block with four replications. The 10 treatments applied included annual or biennial manure or compost application based on $\mathrm{N}$ or $\mathrm{P}$ removal by corn $\left(151 \mathrm{~kg} \mathrm{~N} \mathrm{ha}^{-1}\right.$ and $25.8 \mathrm{~kg} \mathrm{P}^{-1}$ for an expected yield level of $9.4 \mathrm{Mg} \mathrm{ha}^{-1}$; Gilbertson et al., 1979) and fertilized and unfertilized checks. Fertilizer application was made in the spring each year. The inorganic fertilizer plots received $\mathrm{N}$ as $\mathrm{NH}_{4} \mathrm{NO}_{3}(34-0-0, \mathrm{~N}-\mathrm{P}-\mathrm{K})$ and $\mathrm{P}$ as superphosphate (0-20-0, N-P-K) in 1993, and diammonium phosphate (18-20-0, N-P-K) in 1994, 1995, and 1996. If necessary, the P-based treatments (annual or biennial application) also received $\mathrm{N}$ fertilizer as $\mathrm{NH}_{4} \mathrm{NO}_{3}$ in the spring so that a total of $151 \mathrm{~kg} \mathrm{~N} \mathrm{ha}^{-1}$ was available to the crop.

Beef cattle manure was collected from the feedlot pens in late spring each year and composted for $\approx 4 \mathrm{mo}$, using active composting with turning. Beef cattle feedlot manure (collected in the autumn) and composted feedlot manure were applied in the autumn of 1992 based on the assumption that 40,20, 10 , and $5 \%$ of the total $\mathrm{N}$ in manure or compost would become plant available in the first, second, third, and fourth year after application, respectively, based on a modification of decay series given by Pratt et al. (1973). The first year N availability assumption from compost was found to be too high, based on $\mathrm{N}$ uptake in 1993 (Eghball and Power, 1999), and were changed to $20,20,10$, and $5 \%$ in the first, second, third and fourth year after compost applications in 1993, 1994, and 1995. Hadas and Portnoy (1994) found a N release range of $11 \%$ to $29 \%$ for composted manure. Phosphorus plant-availability assumptions from manure and compost were 40,20,10, and $10 \%$ of total $\mathrm{P}$ in the first, second, third, and fourth year after applications in 1993 and 1994. Phosphorus availability assumptions from manure and compost were changed to 60 , 20, 10, and $10 \%$ for the application years of 1994 and 1995 . The $\mathrm{N}$ and $\mathrm{P}$ availability assumptions are only approximations, as mineralization of organic materials depends on several fac-

Table 1. Characteristics of beef cattle feedlot manure and composted feedlot manure applied in 4 yr at Mead, NE. Nutrients, C and ash contents are on a dry weight basis. Electrical conductivity $(\mathrm{EC})$ and $\mathrm{pH}$ were determined on 2:1 water to dry manure or compost ratio.

\begin{tabular}{|c|c|c|c|c|c|c|c|c|c|}
\hline \multirow[t]{2}{*}{$\begin{array}{l}\text { Year and } \\
\text { source }\end{array}$} & Total C & Total N & Total P & Ash & $\begin{array}{l}\text { Water } \\
\text { content }\end{array}$ & $\mathbf{N O}_{3}-\mathbf{N}$ & $\mathbf{N H}_{4}-\mathbf{N}$ & $\mathbf{E C}$ & pH \\
\hline & \multicolumn{5}{|c|}{$\longrightarrow \mathrm{g} \mathrm{kg}^{-1}$} & \multicolumn{2}{|c|}{$\mathrm{mg} \mathrm{kg}^{-1}$} & \multicolumn{2}{|l|}{ dS $\mathbf{m}^{-1}$} \\
\hline \multicolumn{10}{|l|}{1992} \\
\hline Manure & 78.4 & 7.9 & 2.29 & 844 & 195 & 30 & 1263 & 4.6 & 7.3 \\
\hline Compost & 95.0 & 11.0 & 4.18 & 808 & 332 & 117 & 169 & 7.4 & 7.7 \\
\hline \multicolumn{10}{|l|}{1993} \\
\hline Manure & 133.1 & 10.2 & 5.00 & 715 & 539 & 17 & 480 & 5.2 & 8.8 \\
\hline Compost & 87.4 & 7.7 & 3.16 & 796 & 403 & 38 & 33 & 2.2 & 8.3 \\
\hline \multicolumn{10}{|l|}{1994} \\
\hline Manure & 237.0 & 15.6 & 3.27 & 591 & 200 & 11 & 365 & 5.4 & 8.2 \\
\hline Compost & 73.5 & 7.6 & 4.07 & 849 & 340 & 383 & 55 & 6.1 & 7.2 \\
\hline \multicolumn{10}{|l|}{1995} \\
\hline Manure & 172.8 & 13.0 & 3.16 & 677 & 251 & 130 & 898 & 3.8 & 7.3 \\
\hline Compost & 68.2 & 7.8 & 3.05 & 798 & 150 & 294 & 97 & 6.0 & 7.7 \\
\hline
\end{tabular}




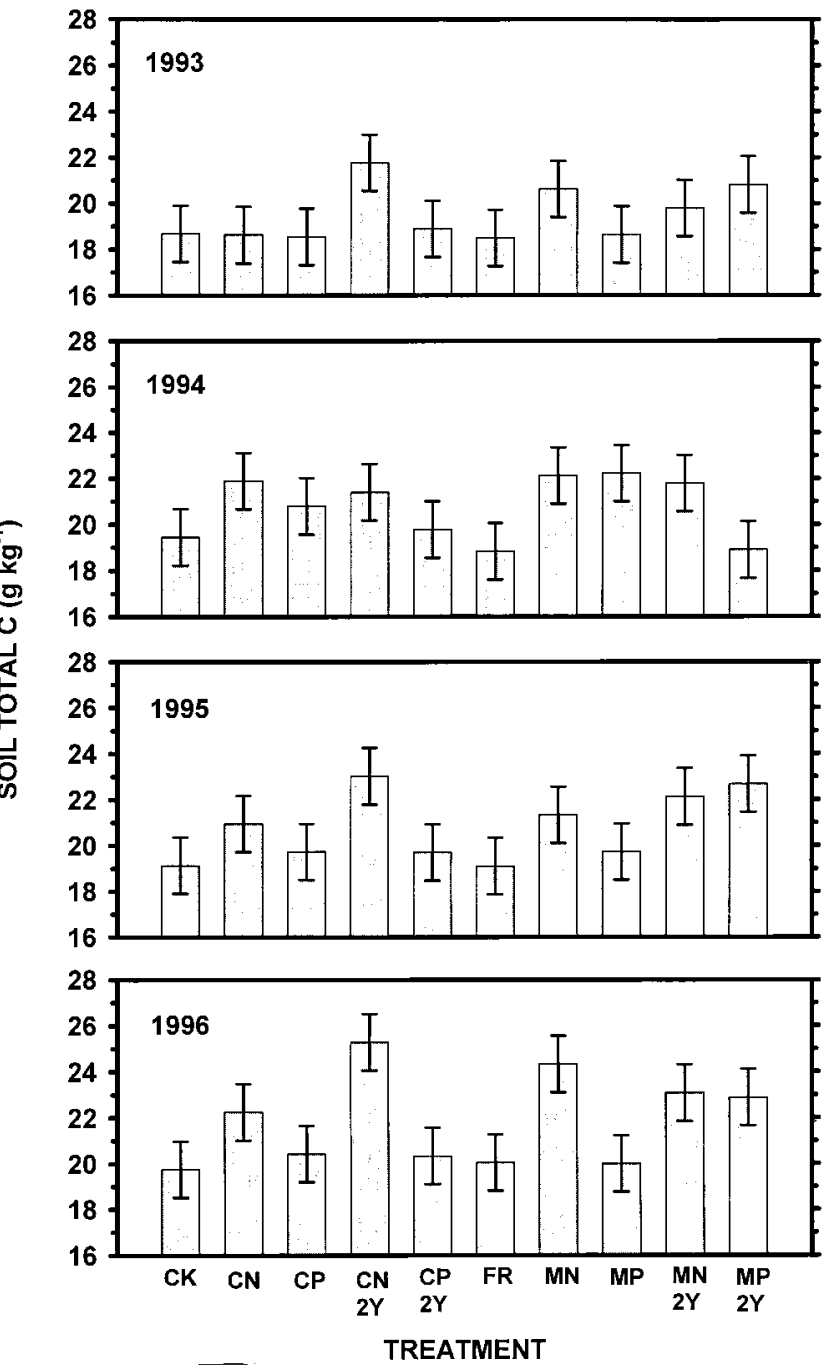

Fig. 1. Surface soil $(0-15 \mathrm{~cm})$ total carbon concentration for 10 treatments in $4 \mathrm{yr}$. The vertical bars are standard errors, $\mathrm{CN}$ is compost for $N, C P$ is compost for $P, M N$ is manure for $N$, MP is manure for $\mathrm{P}, \mathrm{FR}$ is inorganic fertilizer, $\mathrm{CK}$ is check, and $2 \mathrm{Y}$ is biennial application.

tors that vary from year to year (temperature, moisture, organic matter composition, and soil/organic matter contact).

Biennial manure or compost applications were made to provide $151 \mathrm{~kg} \mathrm{~N}^{-1}$ for $\mathrm{N}$-based rates and $25.8 \mathrm{~kg} \mathrm{P}^{-1}$ for P-based rates in the second year after application, based on the assumptions given above. Overapplication of $\mathrm{N}$ and $\mathrm{P}$ were made in the first year of application for the biennial manure and compost treatments. Residual $\mathrm{N}$ and $\mathrm{P}$ values, based on the availability assumptions from previous years, were considered when manure or compost was applied.

Manure or compost application was made in late autumn after corn harvest. Manure and compost were applied by hand to plots $12.2-\mathrm{m}$ long and $4.6-\mathrm{m}$ wide (6 corn rows). Manure and compost characteristics are given in Table 1 . Manure characteristic are influenced by species and age of the animal, ration fed, collection and storage method, and climate. These can cause variability in manure composition from year to year. Total $\mathrm{N}$ in manure and compost was determined on air-dried samples (corrected for ammonium loss during drying) based on the method described by Schepers et al. (1989). Total P was determined on air-dried manure and compost samples based on the Knudsen et al. (1981) method in 1992 and 1993.

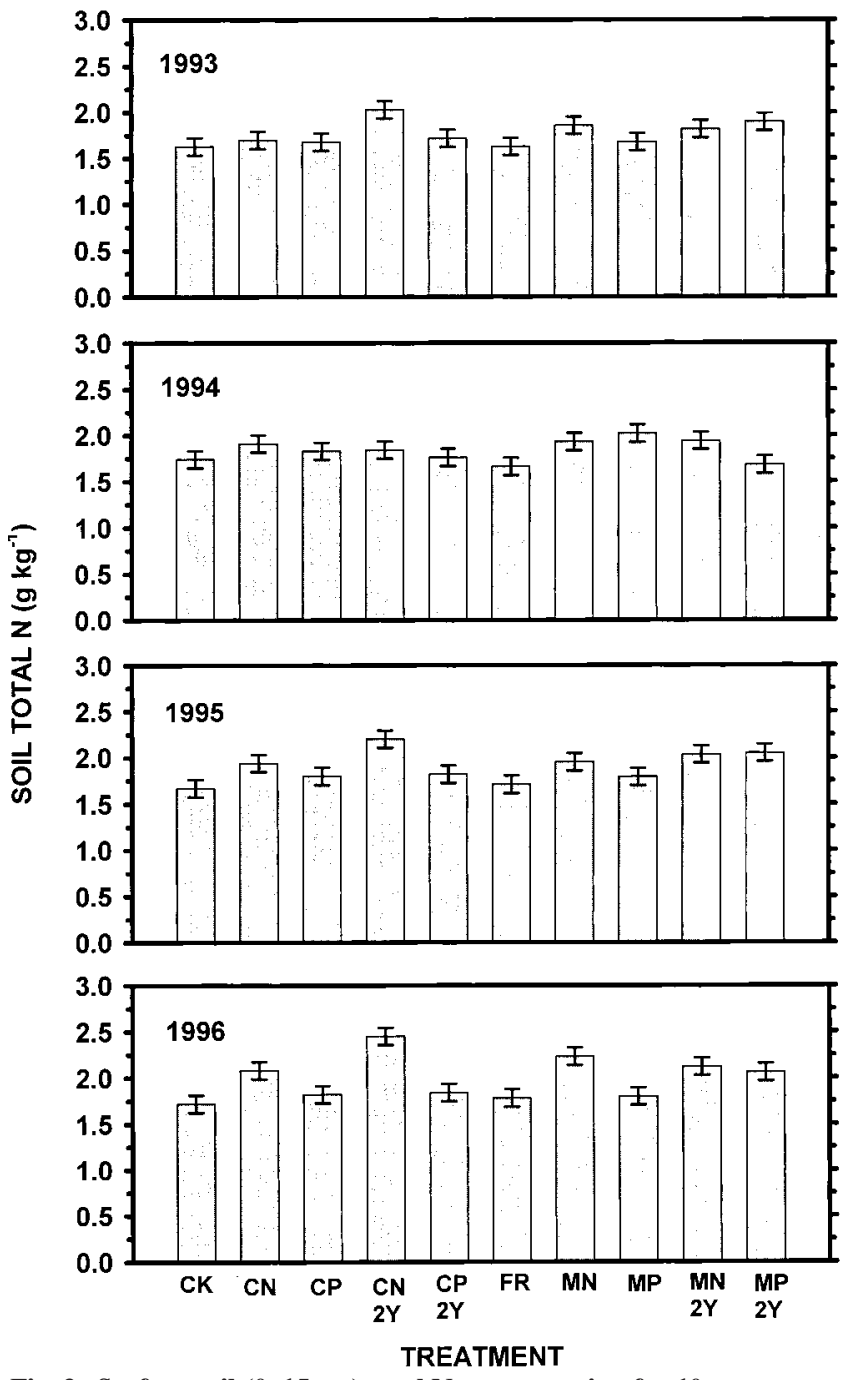

Fig. 2. Surface soil $(0-15 \mathrm{~cm})$ total $N$ concentration for 10 treatments in $4 \mathrm{yr}$. The vertical bars are standard errors, $\mathrm{CN}$ is compost for $\mathrm{N}, \mathrm{CP}$ is compost for $\mathrm{P}, \mathrm{MN}$ is manure for $\mathrm{N}, \mathrm{MP}$ is manure for $\mathrm{P}, \mathrm{FR}$ is inorganic fertilizer, $\mathrm{CK}$ is check, and $2 \mathrm{Y}$ is biennial application.

and by the Perchloric method in 1994 and 1995 (Johnson and Ulrich, 1959). Nitrate and ammonium were determined by extracting wet manure and compost samples with $2 \mathrm{M} \mathrm{KCl}$ and then using a Lachat system (Zellweger Analytics, Milwaukee, WI). The high ash contents of manure and compost reflect inclusion of soil by the animal hoof action during wet periods or by scrapping feedlot soil when manure is collected from the feedlot surface. The amounts of manure and compost, and $\mathrm{N}$ and $\mathrm{P}$ applied for each treatment are given in Table 2. Manure and compost were applied and incorporated to the top $10-\mathrm{cm}$ soil by disking within $2 \mathrm{~d}$ after application. Corn (Pioneer brand hybrid 3394) was planted at a seeding rate of 47000 seeds $\mathrm{ha}^{-1}$ and a row spacing of $0.76 \mathrm{~m}$. Weed control was achieved by band application of herbicide in the corn rows at planting and by cultivation. Additional information regarding corn yield and $\mathrm{N}$ and $\mathrm{P}$ uptake is reported in Eghball and Power (1999).

Soil samples to a depth of $1.2 \mathrm{~m}$ were collected from all plots each year after corn harvest. The soil samples were divided into 0- to $15-, 15-$ to $30-, 30-$ to $60-, 60-$ to $90-$, and $90-$ to $120-\mathrm{cm}$ increments. The soil samples were air-dried and analyzed for total $\mathrm{N}$ and $\mathrm{C}$, nitrate, ammonium, $\mathrm{pH}$, and $\mathrm{EC}$. The total soil $\mathrm{N}$ and $\mathrm{C}$ were determined on the basis of the 

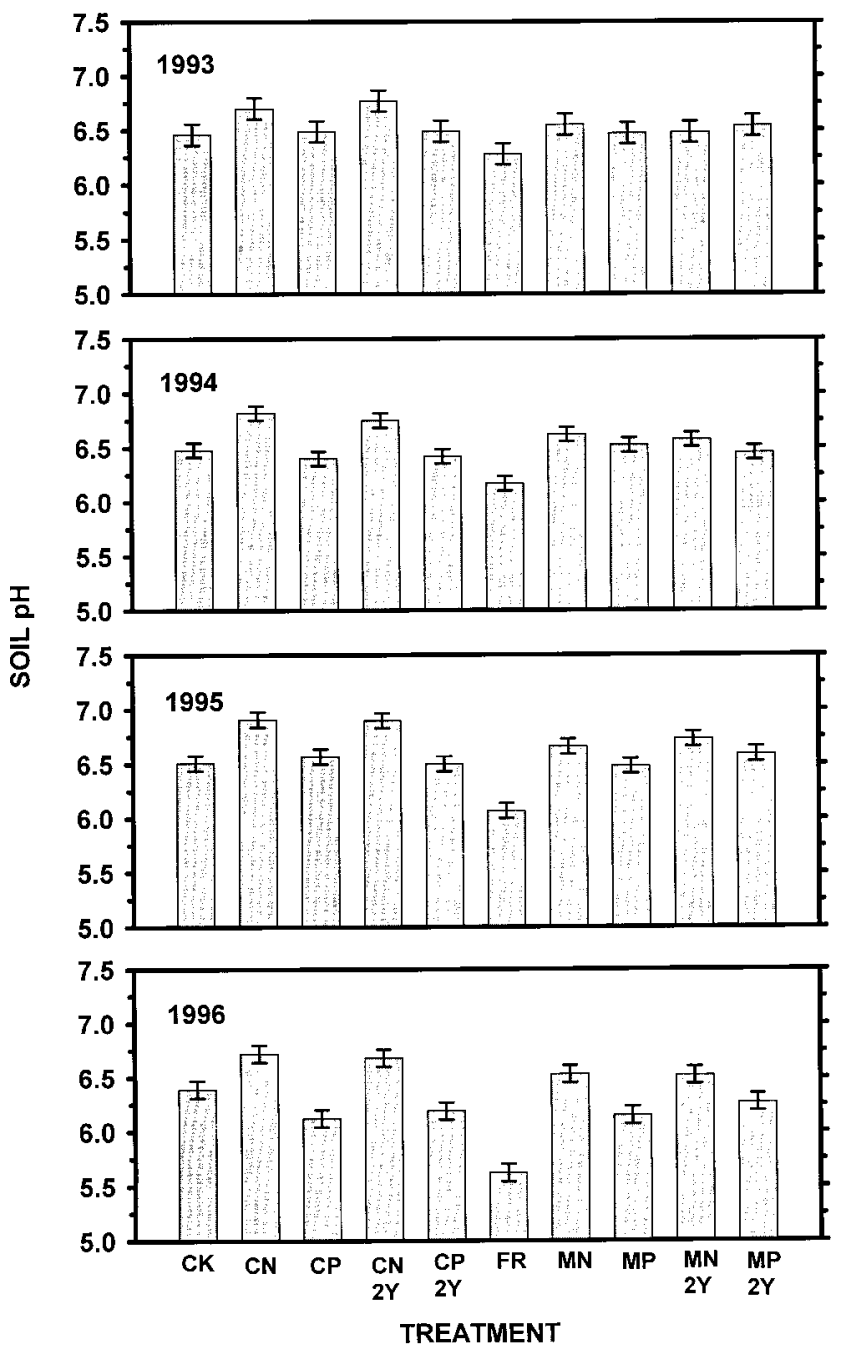

Fig. 3. Surface soil (0-15 cm) pH for 10 treatments in $4 \mathrm{yr}$. The vertical bars are standard errors, $\mathrm{CN}$ is compost for $\mathrm{N}, \mathrm{CP}$ is compost for $P, M N$ is manure for $N, M P$ is manure for $P, F R$ is inorganic fertilizer, CK is check, and $2 \mathrm{Y}$ is biennial application.

method described in Schepers et al. (1989), and $\mathrm{NO}_{3}-\mathrm{N}$ and $\mathrm{NH}_{4}-\mathrm{N}$ were determined by extracting with $2 \mathrm{M} \mathrm{KCl}$ and using a Lachat system. Soil bulk density was determined for the depth increments in the autumns of 1994 and 1996. Three soil samples (4.5-cm diam.) were collected from each plot (between rows) and composited into the above increments. Bulk density was determined by determining the soil dry weight (dried at $110^{\circ} \mathrm{C}$ ) and volume of the soil sample.

Analysis of variance was used to analyze the data using PROC MIXED of SAS (SAS Inst., Cary, NC; Littell et al., 1996). Year and depth increments were used as repeated observations in this analysis. A probability level of $\leq 0.05$ was considered significant.

\section{RESULTS AND DISCUSSION}

Significant year $\times$ treatment interactions were observed for the surface soil $(0-15 \mathrm{~cm})$ total $\mathrm{N}$ and total $\mathrm{C}$ concentrations and $\mathrm{pH}$ and $\mathrm{EC}$ levels (Table 3 ). Total $\mathrm{N}$ and $\mathrm{C}$ quantities were significantly influenced by year of sampling (Table 3). These quantities increased with increasing years of manure and compost applications. Total C concentration in the surface soil was generally
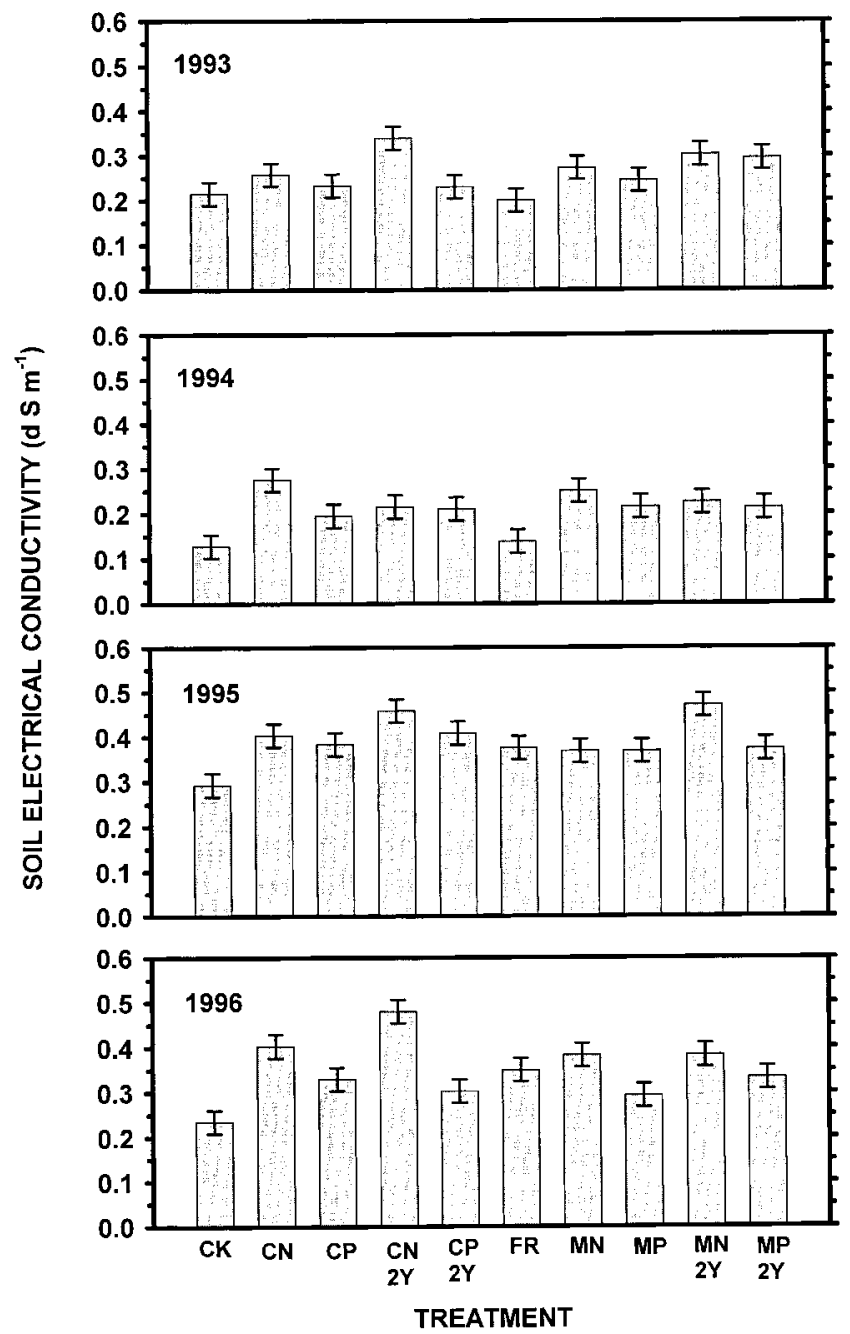

Fig. 4. Surface soil (0-15 cm) electrical conductivity for 10 treatments in $4 \mathrm{yr}$. The vertical bars are standard errors, $\mathrm{CN}$ is compost for $N$, CP is compost for $P, M N$ is manure for $N, M P$ is manure for P, FR is inorganic fertilizer, $\mathrm{CK}$ is check, and $2 \mathrm{Y}$ is biennial application.

greater for $\mathrm{N}$ - than P-based manure and compost applications, and the differences became greater with years of application (Fig. 1), indicating the cumulative effects of manure and compost application. Total $\mathrm{N}$ concentrations for the treatments across years had a similar pattern as the total $\mathrm{C}$ concentration (Fig. 2). Biennial $\mathrm{N}$-based compost treatment resulted in greater soil surface $(0-15 \mathrm{~cm}) \mathrm{C}$ and $\mathrm{N}$ concentrations than annual $\mathrm{N}-$ based compost in the fourth year (1996), even though similar total amounts of compost were applied for both treatments in $4 \mathrm{yr}$ (Fig. 1 and 2; Table 2). This indicates that heavy application of compost every other year may protect the $\mathrm{C}$ and $\mathrm{N}$ from mineralization, as compared with smaller annual rates.

Following 4 yr of applications, total $\mathrm{C}$ content in the 0 - to $15-\mathrm{cm}$ soil was 44.5 for MN, 38.1 for manure application for corn P needs (MP), 43.7 for manure for corn $\mathrm{N}$ needs for $2 \mathrm{yr}(\mathrm{MN} 2 \mathrm{Y}), 44.9$ for manure for corn $\mathrm{P}$ needs for $2 \mathrm{yr}, 43.6$ for $\mathrm{CN}, 41.7$ for compost for corn $\mathrm{P}$ needs (CP), 47.2 for compost for corn $\mathrm{N}$ needs for $2 \mathrm{yr}, 39.4$ for compost for corn P for $2 \mathrm{yr}, 40.2$ for ferti- 
Table 2. Composted and noncomposted manure dry weight, and $N$ and $P$ application rates in 4 yr at Mead, NE.

\begin{tabular}{|c|c|c|c|c|c|c|c|c|c|c|c|c|}
\hline \multirow[b]{2}{*}{ Treatment } & \multicolumn{4}{|c|}{ Dry weight } & \multicolumn{4}{|c|}{$\mathbf{N}$} & \multicolumn{4}{|c|}{$\mathbf{P}$} \\
\hline & 1992 & 1993 & 1994 & 1995 & 1992 & 1993 & 1994 & 1995 & 1992 & 1993 & 1994 & 1995 \\
\hline & \multicolumn{4}{|c|}{$-\mathrm{Mg} \mathrm{ha}^{-1}$} & \multicolumn{8}{|c|}{$-\mathrm{kg} \mathrm{ha}^{-1}$} \\
\hline Manure for $\mathbf{N}$ & 46.9 & 18.5 & 12.1 & 14.5 & 378 & 189 & 189 & 189 & 107 & 92 & 40 & 46 \\
\hline Manure for $\mathbf{P}$ & 28.3 & 6.4 & 6.6 & 2.7 & $227(60) \dagger$ & $66(80)$ & $103(74)$ & $35(99)$ & 64 & 32 & 21 & $8+$ \\
\hline Manure for $\mathrm{N} / 2 \mathrm{yr}$ & 93.9 & - & 36.3 & - & 756 & - & 567 & - & 214 & - & 119 & - \\
\hline Manure for $\mathbf{P} / 2 \mathrm{yr}$ & 56.4 & - & 19.8 & - & 454 & $-(60)$ & 308 & $-(67)$ & 129 & - & 64 & - \\
\hline Compost for $\mathbf{N}$ & 34.6 & 49.5 & 25.1 & 36.4 & 378 & 378 & 189 & 283 & 144 & 156 & 102 & 111 \\
\hline Compost for $\mathbf{P}$ & 15.5 & 10.3 & 5.3 & 2.9 & $168(84)$ & 78 (102) & $40(111)$ & $22(123)$ & 64 & 32 & 21 & $9 \%$ \\
\hline Compost for $\mathrm{N} / 2 \mathrm{yr}$ & 69.4 & - & 75.2 & - & 756 & - & 567 & - & 289 & - & 305 & - \\
\hline Compost for $P / 2 y r$ & 31.0 & - & 15.9 & - & 337 (16) & $-(84)$ & $120(94)$ & $-(110)$ & 129 & - & 64 & - \\
\hline Fertilizer & - & - & - & - & 151 & 151 & 151 & 151 & 26 & 26 & 26 & 26 \\
\hline
\end{tabular}

$\uparrow$ Numbers in parentheses are $\mathrm{kg} \mathrm{N} \mathrm{ha}^{-1}$ applied as $\mathrm{NO}_{3} \mathrm{NH}_{4}$ fertilizer.

$+\mathrm{P}$ application rate was $\approx 7 \mathrm{~kg} \mathrm{ha}^{-1}$ less than the expected plant $\mathrm{P}$ uptake $\left(26 \mathrm{~kg} \mathrm{ha}^{-1}\right)$.

Table 3. Effects of year and treatment on surface $(0-15 \mathrm{~cm})$ soil $\mathrm{N}, \mathrm{C}$, pH and electrical conductivity (EC), and analysis of variance.

\begin{tabular}{|c|c|c|c|c|c|c|c|c|}
\hline Variables & df & $n$ & $\begin{array}{c}\text { Total N } \\
\text { concentration }\end{array}$ & $\begin{array}{c}\text { Total C } \\
\text { concentration }\end{array}$ & $\begin{array}{c}\text { Total N } \\
\text { quantity }\end{array}$ & $\begin{array}{c}\text { Total C } \\
\text { quantity }\end{array}$ & pH & EC \\
\hline & & & $\longrightarrow$ & 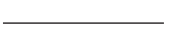 & $\longrightarrow$ & 1 & & dS $\mathrm{m}^{-1}$ \\
\hline \multicolumn{9}{|l|}{ Year } \\
\hline 1993 & & 40 & 1.76 & 19.5 & 3.4 & 37.9 & 6.52 & 0.26 \\
\hline 1994 & & 40 & 1.83 & 20.7 & 3.6 & 40.4 & 6.52 & 0.21 \\
\hline 1995 & & 40 & 1.90 & 20.7 & 3.7 & 40.2 & 6.59 & 0.39 \\
\hline 1996 & & 40 & 1.99 & 21.8 & 3.8 & 42.2 & 6.32 & 0.35 \\
\hline $\mathbf{L S D}_{0.05}$ & & & 0.07 & 0.8 & 0.2 & 2.3 & 0.06 & 0.02 \\
\hline \multicolumn{9}{|l|}{ Treatment } \\
\hline Manure for $\mathbf{N}$ & & 16 & 1.99 & 22.1 & 3.8 & 42.7 & 6.59 & 0.32 \\
\hline Manure for $\mathbf{P}$ & & 16 & 1.82 & 20.2 & 3.5 & 38.6 & 6.40 & 0.28 \\
\hline Manure for $\mathbf{N}, 2$ yr & & 16 & 1.98 & 21.7 & 3.9 & 42.9 & 6.57 & 0.35 \\
\hline Manure for $P, 2$ yr & & 16 & 1.92 & 21.3 & 3.7 & 40.8 & 6.46 & 0.30 \\
\hline Compost for $\mathbf{N}$ & & 16 & 1.91 & 20.9 & 3.7 & 40.3 & 6.79 & 0.33 \\
\hline Compost for $P$ & & 16 & 1.78 & 19.9 & 3.5 & 39.2 & 6.39 & 0.29 \\
\hline Compost for $\mathbf{N}, 2 \mathrm{yr}$ & & 16 & 2.13 & 22.9 & 4.0 & 43.4 & 6.78 & 0.37 \\
\hline Compost for $P, 2$ yr & & 16 & 1.79 & 19.7 & 3.5 & 38.4 & 6.40 & 0.29 \\
\hline Fertilizer & & 16 & 1.69 & 19.1 & 3.3 & 37.8 & 6.03 & 0.27 \\
\hline Check & & 16 & 1.69 & 19.3 & 3.3 & 37.6 & 6.46 & 0.22 \\
\hline \multirow[t]{2}{*}{$\mathbf{L S D}_{0.05}$} & & & 0.20 & 2.8 & 0.4 & 5.6 & 0.16 & 0.04 \\
\hline & \multicolumn{8}{|c|}{$\underline{P}>\boldsymbol{F}$} \\
\hline \multicolumn{9}{|l|}{ ANOVA } \\
\hline Year & 3 & & 0.01 & 0.01 & 0.01 & 0.01 & 0.01 & 0.01 \\
\hline Treatment & 9 & & 0.01 & 0.13 & 0.01 & 0.28 & 0.01 & 0.01 \\
\hline Year $\times$ treatment & 27 & & 0.01 & 0.02 & 0.06 & 0.24 & 0.02 & 0.04 \\
\hline
\end{tabular}

Table 4. Effects of year and treatment on soil N, C, pH and electrical conductivity (EC) at 15 to $30 \mathrm{~cm}$, and analysis of variance.

\begin{tabular}{|c|c|c|c|c|c|c|c|c|}
\hline Variables & df & $n$ & $\begin{array}{c}\text { Total } \mathbf{N} \\
\text { concentration }\end{array}$ & $\begin{array}{c}\text { Total C } \\
\text { concentration }\end{array}$ & $\begin{array}{r}\text { Total N } \\
\text { quantity }\end{array}$ & $\begin{array}{c}\text { Total C } \\
\text { quantity }\end{array}$ & $\mathbf{p H}$ & $\mathbf{E C}$ \\
\hline & & & 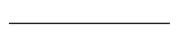 & 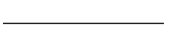 & -1 & 1 & & dS $\mathbf{m}^{-1}$ \\
\hline \multicolumn{9}{|l|}{ Year } \\
\hline 1993 & & 40 & 1.55 & 18.6 & 3.2 & 37.8 & 6.44 & 0.22 \\
\hline 1994 & & 40 & 1.83 & 20.9 & 3.7 & 42.6 & 6.52 & 0.17 \\
\hline 1995 & & 40 & 1.59 & 18.5 & 3.4 & 39.3 & 6.38 & 0.23 \\
\hline 1996 & & 40 & 1.61 & 19.0 & 3.4 & 40.4 & 6.35 & 0.25 \\
\hline $\mathbf{L S D}_{0.05}$ & & & 0.06 & 0.8 & 0.2 & 2.3 & 0.05 & 0.01 \\
\hline \multicolumn{9}{|l|}{ Treatment } \\
\hline Manure for $\mathbf{N}$ & & 16 & 1.69 & 19.9 & 3.6 & 42.6 & 6.37 & 0.21 \\
\hline Manure for $\mathbf{P}$ & & 16 & 1.60 & 18.6 & 3.2 & 37.7 & 6.52 & 0.20 \\
\hline Manure for $\mathrm{N}, 2 \mathrm{yr}$ & & $\begin{array}{l}10 \\
16\end{array}$ & 1.62 & $\begin{array}{l}10.0 \\
18.7\end{array}$ & 3.5 & 39.8 & 6.40 & 0.22 \\
\hline Manure for $\mathbf{P}, 2 \mathrm{yr}$ & & 16 & 1.67 & 20.0 & 3.4 & 41.2 & 6.37 & 0.22 \\
\hline Compost for $\mathbf{N}$ & & 16 & 1.62 & 18.7 & 3.4 & 38.7 & 6.56 & 0.22 \\
\hline Compost for $\mathbf{P}$ & & 16 & 1.64 & 19.2 & 3.4 & 39.5 & 6.50 & 0.21 \\
\hline Compost for $\mathrm{N}, 2 \mathrm{yr}$ & & 16 & 1.70 & 20.0 & 3.6 & 42.2 & 6.39 & 0.26 \\
\hline Compost for $\mathbf{P}, 2 \mathrm{yr}$ & & 16 & 1.62 & 19.0 & 3.5 & 40.8 & 6.39 & 0.21 \\
\hline Fertilizer & & 16 & 1.67 & 19.4 & 3.4 & 39.1 & 6.37 & 0.24 \\
\hline Check & & 16 & 1.61 & 18.9 & 3.3 & 38.5 & 6.40 & 0.19 \\
\hline \multirow[t]{2}{*}{$\mathbf{L S D}_{0.05}$} & & & 0.18 & 2.8 & 0.4 & 6.5 & 0.21 & $\mathbf{0 . 0 3}$ \\
\hline & \multicolumn{8}{|c|}{$\underline{P}>\boldsymbol{F}$} \\
\hline \multicolumn{9}{|l|}{ ANOVA } \\
\hline Year & 3 & & 0.01 & 0.01 & 0.01 & 0.01 & 0.01 & 0.01 \\
\hline Treatment & 9 & & 0.96 & 0.95 & 0.71 & 0.82 & 0.48 & 0.01 \\
\hline Year $\times$ treatment & 27 & & 0.18 & 0.12 & 0.45 & 0.32 & 0.99 & 0.14 \\
\hline
\end{tabular}




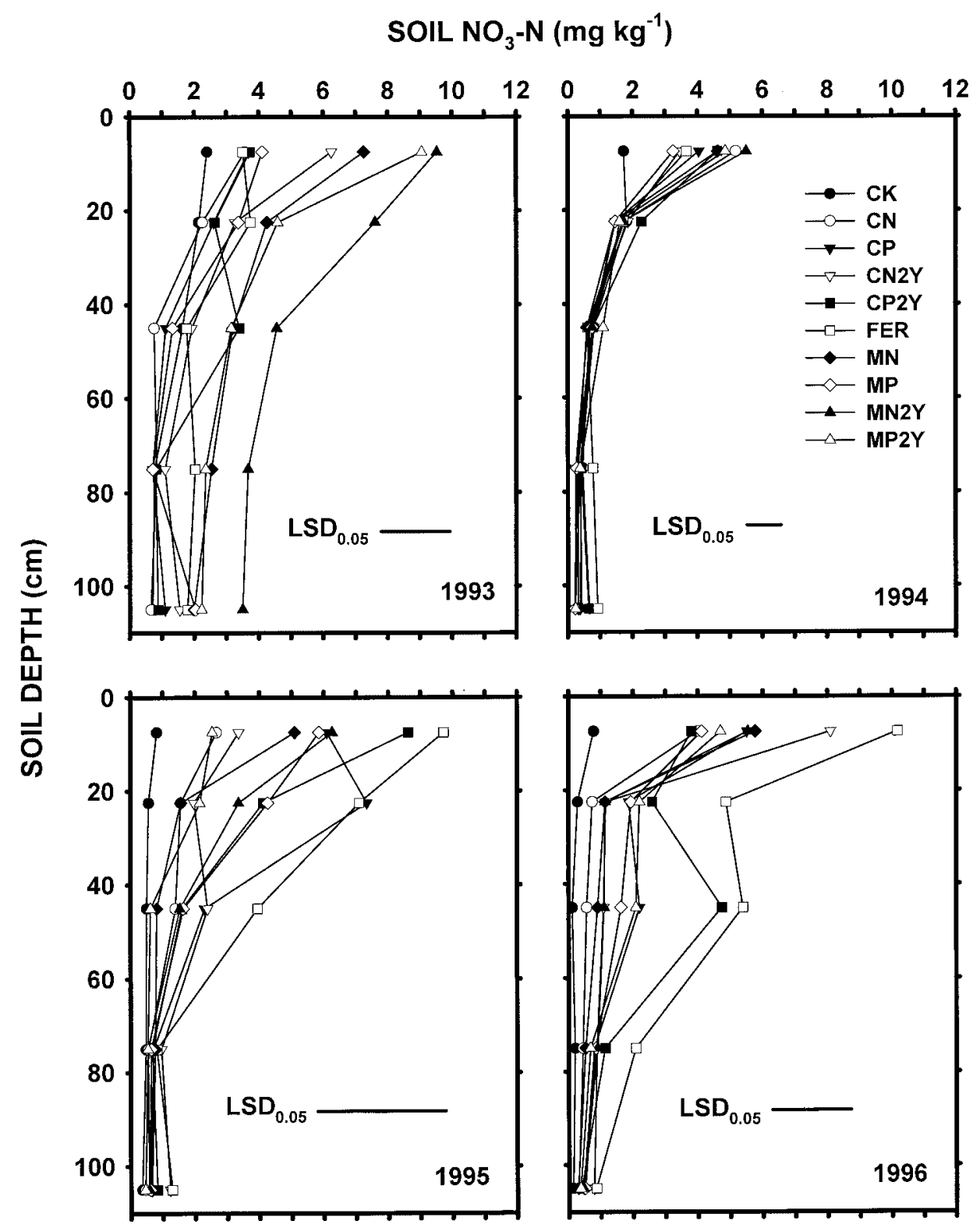

Fig. 5. Soil nitrate-N concentration to a depth of $1.2 \mathrm{~m}$ for 10 treatments in $4 \mathrm{yr}$. $\mathrm{CN}$ is compost for $\mathrm{N}$, $\mathrm{CP}$ is compost for $\mathrm{P}$, MN is manure for $\mathrm{N}, \mathrm{MP}$ is manure for P, FR is inorganic fertilizer, CK is check, and $2 \mathrm{Y}$ is biennial application.

lizer, and $38.6 \mathrm{Mg} \mathrm{ha}^{-1}$ for the check treatment in the fourth yr (1996), with a $\mathrm{LSD}_{0.05}$ value of $3.3 \mathrm{Mg} \mathrm{ha}^{-1}$. This indicates that manure and compost can increase $\mathrm{C}$ sequestration in the soil, which may have implications for global climate change. On the basis of the 1996 soil $\mathrm{C}$ values and the amount of $\mathrm{C}$ applied from 1992 to 1995 (Tables 1 and 2), $\approx 25 \%$ of applied manure $\mathrm{C}$ and $36 \%$ of applied compost $\mathrm{C}$ remained in the soil after 4 $\mathrm{yr}$ of application (soil $\mathrm{C}$ increase above the fertilizer treatment), indicating more stable $\mathrm{C}$ compounds in compost than in manure. A greater fraction of applied $\mathrm{C}$ remained in the soil from compost application even though cumulative C application rate from 1992 to 1995 was less for compost $\left(7780 \mathrm{~kg} \mathrm{ha}^{-1}\right)$ than for manure (10 $420 \mathrm{~kg} \mathrm{ha}^{-1}$ ) when averaged across treatments.

After one-time manure or compost applications (1993), surface soil $\mathrm{pH}$ was slightly increased or remained similar to the original soil level (Fig. 3). After
4 yr of $\mathrm{MN}$ or $\mathrm{CN}$, surface soil pH significantly increased as compared with MP, CP, or the original soil level, but decreased with fertilizer application (Fig. 3). Eghball (1999) showed that beef cattle manure and compost contain $\mathrm{CaCO}_{3}$ (added in the diet) that will maintain or increase soil $\mathrm{pH}$ when applied to a low-pH soil. Ammonium nitrate and $\left(\mathrm{NH}_{4}\right)_{2} \mathrm{HPO}_{4}$ applications decreased soil $\mathrm{pH}$ from 6.4 to 5.6 after 4 yr. The acidifying effects of the added $\mathrm{N}$ fertilizer would have been greater if an all-ammonium-N source (i.e., anhydrous ammonia) had been applied. Soil surface $(0-15 \mathrm{~cm})$ EC increased with annual or biennial $\mathrm{MN}$ and $\mathrm{CN}$, as compared with P-based applications, reflecting the differences in application amounts between the two strategies (Fig. 4). Surface soil plant available $\mathrm{P}$ was significantly greater for $\mathrm{N}$-based than for $\mathrm{P}$-based applications, indicating that $\mathrm{P}$ accumulation occurs with N-based applications (Eghball and Power, 1999). 
Table 5. Effects of year, soil depth, and treatment on soil $\mathrm{NO}_{3}-\mathrm{N}, \mathrm{NH}_{4}-\mathrm{N}$, and bulk density, and analysis of variance.

\begin{tabular}{|c|c|c|c|c|c|}
\hline Variables & df & $n$ & $\mathbf{N O}_{3}-\mathbf{N}$ & $\mathbf{N H}_{4}-\mathbf{N}$ & Bulk density \\
\hline & & & - mg & $\mathrm{kg}^{-1}$ & $\mathbf{M g ~ m}^{-3}$ \\
\hline \multicolumn{6}{|c|}{ my ng } \\
\hline 1993 & & 200 & 2.89 & 2.41 & - \\
\hline 1994 & & 200 & 1.49 & 2.50 & 1.39 \\
\hline 1995 & & 200 & 2.31 & 2.00 & - \\
\hline 1996 & & 200 & 2.06 & 0.97 & 1.38 \\
\hline $\mathbf{L S D}_{0.05}$ & & & 0.51 & 0.13 & 0.05 \\
\hline \multicolumn{6}{|l|}{ Soil depth $(\mathrm{cm})$} \\
\hline $0-15$ & & 160 & 4.94 & 2.12 & 1.27 \\
\hline 15-30 & & 160 & 2.64 & 1.91 & 1.35 \\
\hline $30-60$ & & 160 & 1.67 & 1.38 & 1.30 \\
\hline $60-90$ & & 160 & 0.87 & 1.70 & 1.44 \\
\hline $90-120$ & & 160 & 0.81 & 2.74 & 1.57 \\
\hline \multirow{2}{*}{\multicolumn{6}{|c|}{$\begin{array}{l}\text { TSDOto.05 } \\
\text { Treatment }\end{array}$}} \\
\hline & & & & & \\
\hline Manure for $\mathbf{N}$ & & 80 & 2.21 & 1.98 & 1.40 \\
\hline Manure for $\mathbf{P}$ & & 80 & 1.98 & 2.02 & 1.36 \\
\hline Manure for N, 2 yr & & 80 & 2.95 & 1.95 & 1.39 \\
\hline Manure for $\mathbf{P}, 2 \mathrm{yr}$ & & 80 & 2.30 & 1.92 & 1.38 \\
\hline Compost for $\mathbf{N}$ & & 80 & 1.48 & 1.92 & 1.40 \\
\hline Compost for $\mathbf{P}$ & & 80 & 2.21 & 2.01 & 1.39 \\
\hline Compost for $\mathrm{N}, 2 \mathrm{yr}$ & & 80 & 2.13 & 1.86 & 1.38 \\
\hline Compost for $\mathbf{P}, 2 \mathrm{yr}$ & & 80 & 2.43 & 1.95 & 1.38 \\
\hline Fertilizer & & 80 & 3.34 & 2.03 & 1.39 \\
\hline Check & & 80 & 0.84 & 2.06 & 1.39 \\
\hline \multirow[t]{2}{*}{$\operatorname{LSD}_{0.05}$} & & & 0.80 & 0.21 & 0.11 \\
\hline & \multicolumn{5}{|c|}{$\boldsymbol{P}>\boldsymbol{F}$} \\
\hline \multicolumn{6}{|l|}{ ANOVA } \\
\hline Year & $3(1) \dagger$ & & 0.01 & 0.01 & 0.69 \\
\hline Depth & 4 & & 0.01 & 0.01 & 0.01 \\
\hline Treatment & 9 & & 0.01 & 0.69 & 0.99 \\
\hline Year $\times$ depth & 12 (4) & & 0.01 & 0.01 & 0.13 \\
\hline Year $\times$ treatment & 27 (9) & & 0.01 & 0.99 & 0.99 \\
\hline \multirow{2}{*}{$\begin{array}{l}\text { Depth } \times \text { treatment } \\
\text { Year } \times \text { depth } \times \\
\text { treatment }\end{array}$} & 36 & & 0.01 & 0.97 & 0.91 \\
\hline & 108 & & 0.01 & 0.93 & 0.92 \\
\hline
\end{tabular}

$\dagger$ The numbers in the parentheses are df for soil bulk density.

Soil properties in the $15-$ to $30-\mathrm{cm}$ increment were not affected by the treatments except EC (Table 4). Total $\mathrm{C}$ and total $\mathrm{N}$ concentrations and quantities were different among years (Table 4). This was mainly due to higher levels of these parameters in 1994 than other years. Soil EC increased, but $\mathrm{pH}$ decreased with year of application in the 15- to $30-\mathrm{cm}$ soil increment (Table 4). This result indicates movement of salt and perhaps $\mathrm{NH}_{4}-\mathrm{N}$ (Table 5) to lower soil depth from surface-applied manure, compost, and inorganic fertilizer applications. Nitrification of $\mathrm{NH}_{4}-\mathrm{N}$ in the $15-$ to $30-\mathrm{cm}$ soil seemed to have lowered the $\mathrm{pH}$.

There was a significant year $\times$ soil depth $\times$ treatment interaction for soil nitrate concentration (Table 5). Soil nitrate concentrations were similar for all treatments in 1994, the year with the highest yield (Eghball and Power, 1999), but fertilizer application resulted in significantly more soil $\mathrm{NO}_{3}-\mathrm{N}$ than other treatments in 1995 and 1996, which were both drier than 1994 (Fig. 5). Soil ammonium concentration decreased with year of application (Table 5). There was a significant year $\times$ soil depth interaction for $\mathrm{NH}_{4}-\mathrm{N}$ concentration. Ammonium-N concentration for the $30-$ to $60-\mathrm{cm}$ (containing a sandy layer of $\approx 20 \mathrm{~cm}$ ) soil depth increment was lower than other soil depths in 1993, 1995, and 1996, but was highest in 1995 (data not shown).

Total quantity of soil nitrate to a depth of $1.2 \mathrm{~m}$ was significantly influenced by a year $\times$ treatment interaction $(P=0.01)$. Soil nitrate quantity to a depth of 1.2
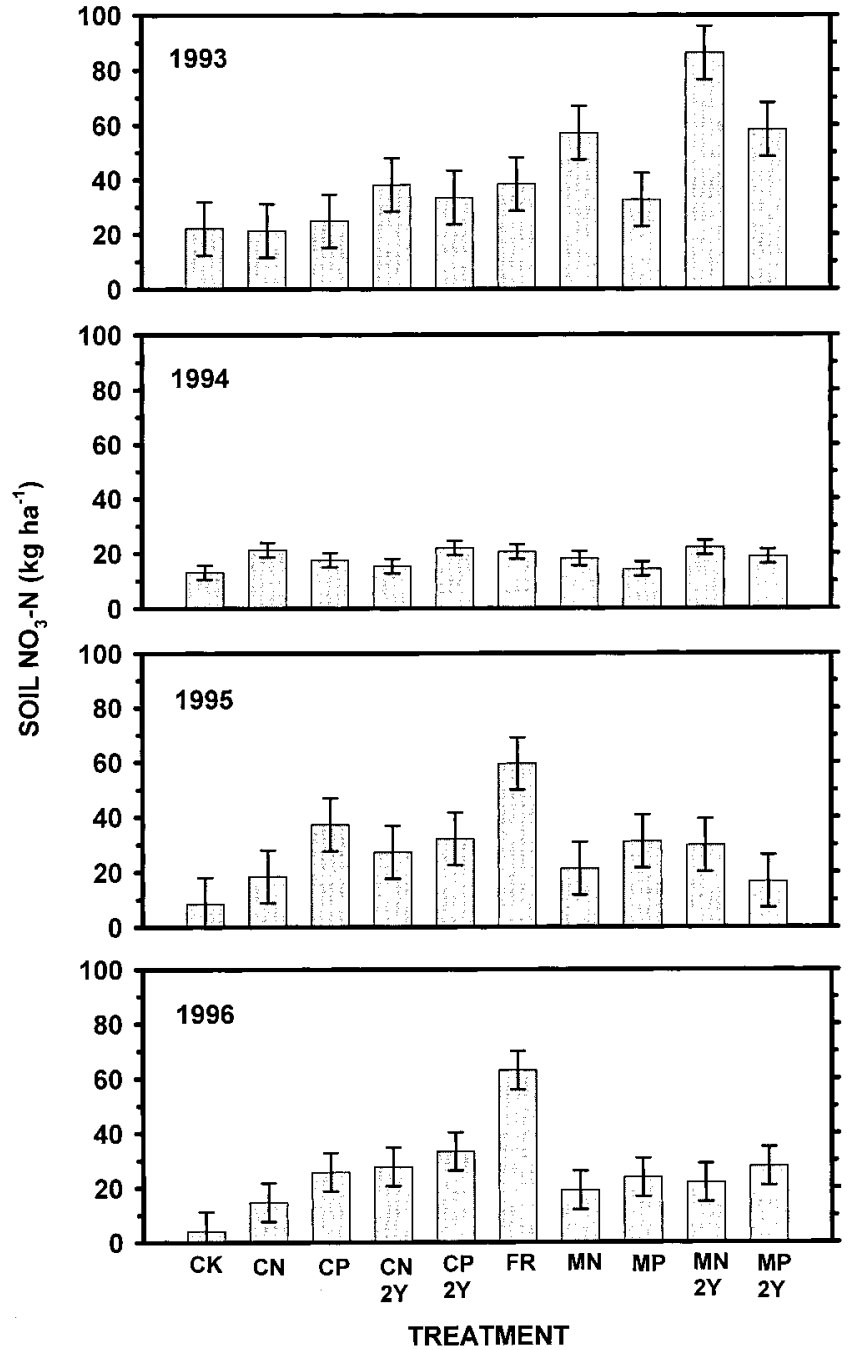

Fig. 6. Soil nitrate-N quantity to a depth of $1.2 \mathrm{~m}$ for $\mathbf{1 0}$ treatments in $4 \mathrm{yr}$. The vertical bars are standard errors, $\mathrm{CN}$ is compost for $\mathrm{N}, \mathrm{CP}$ is compost for $\mathrm{P}, \mathrm{MN}$ is manure for $\mathrm{N}, \mathrm{MP}$ is manure for $\mathrm{P}, \mathrm{FR}$ is inorganic fertilizer, $\mathrm{CK}$ is check, and $2 \mathrm{Y}$ is biennial application.

$\mathrm{m}$ was similar between manure and compost treatments in all years, except MN2Y in 1993 which was higher than other treatments, but was significantly greater for fertilizer than manure, compost, and check treatments in 1995 and 1996 (Fig. 6). This indicates that nitrate accumulation from inorganic fertilizer might be greater than manure and compost in drier years. Soil $\mathrm{NH}_{4}-\mathrm{N}$ quantity to a depth of $1.2 \mathrm{~m}$ was not significantly influenced by treatment or year $\times$ treatment interaction, but significantly decreased with year of application. The $\mathrm{NH}_{4}-\mathrm{N}$ quantities were $42,42,34$, and $16 \mathrm{~kg} \mathrm{ha}^{-1}$ in 1993, 1994, 1995, and 1996, respectively.

Soil bulk density was unaffected by the treatments (Table 5). The amount of organic matter applied to this silty clay loam soil, with an original organic matter content of $31 \mathrm{~g} \mathrm{~kg}^{-1}$, was not enough to make a significant difference in soil bulk density.

\section{SUMMARY}

Soil $\mathrm{C}$ and $\mathrm{N}$ concentrations were greater for annual or biennial N-based applications than MP and CP after 
$4 \mathrm{yr}$, reflecting the differences in application rates. Soil nitrate concentrations and quantities were similar for manure, compost, and fertilizer treatments in the best corn-producing year (1994), but were much greater for fertilizer than manure and compost treatments in the drier years (1995 and 1996). In the drier years, less $\mathrm{N}$ in manure and compost was mineralized, and residual build up of soil $\mathrm{NO}_{3}$ was not expected. Soil pH was increased or maintained near the original soil level when $\mathrm{N}$-based manure or compost was applied, but was significantly reduced with the application of $\mathrm{NH}_{4}-\mathrm{N}$. Manure and composted manure contained $\approx 9 \mathrm{~g} \mathrm{CaCO}_{3} \mathrm{~kg}^{-1}$ (lime was added to the beef cattle diet), indicating potential liming effects of manure or compost. Soil EC level increased with increasing rates of manure or compost application. Soil bulk density was unaffected by manure, compost, or fertilizer application, indicating that the amount of organic matter applied was not enough to change the soil bulk density in this silty clay loam soil with an original organic matter content of 31 $\mathrm{g} \mathrm{kg}^{-1}$. Changes in soil properties were greater for annual or biennial $\mathrm{CN}$ and $\mathrm{MN}$ than $\mathrm{CP}$ and MP, probably because greater amounts of manure and compost were applied with $\mathrm{N}$ - than P-based strategy. Annual or biennial $\mathrm{MN}$ or $\mathrm{CN}$ rates can be made to less productive or degraded areas within a field where potential for P loss in runoff is negligible. Soil P levels will eventually increase with N-based applications, and needs to be considered when subsequent manure or compost additions are made to the soil.

\section{REFERENCES}

Chang, C., and H.H. Janzen. 1996. Long-term fate of nitrogen from annual feedlot manure applications. J. Environ. Qual. 25:785-790.

Chang, C., T.G. Sommerfeldt, and T. Entz. 1991. Soil chemistry after eleven annual applications of cattle feedlot manure. J. Environ. Qual. 20:475-480.

Davis, J.G., M. Young, and B. Ahnstedt. 1997. Soil characteristics of cropland fertilized with feedlot manure in the South Platte river basin of Colorado. J. Soil Water Conserv. 97:327-331.

Eghball, B. 1999. Liming effects of beef cattle feedlot manure or compost. Commun. Soil Sci. Plant Anal. 30:2563-2570.

Eghball, B., and J.F. Power. 1999. Phosphorus and nitrogen-based manure and compost application: Corn production and soil phosphorus. Soil Sci. Soc. Am. J. 63:895-901.
Eghball, B., J.F. Power, J.E. Gilley, and J.W. Doran. 1997. Nutrient, carbon, and mass loss of beef cattle feedlot manure during composting. J. Environ. Qual. 26:189-193.

Fraser, D.G., J.W. Doran, W.W. Sahs, and G.W. Lesoing. 1988. Soil microbial populations and activities under conventional and organic management. J. Environ. Qual. 17:585-590.

Gao, G., and C. Chang. 1996. Changes in CEC and particle size distribution of soils associated with long-term annual applications of cattle feedlot manure. Soil Science 161:115-120.

Gilbertson, C.B., F.A. Norstadt, A.C. Mathers, R.F. Holt, L.R Shuyler, A.P. Barnett, T.M. McCalla, C.A. Onstad, R.A. Young, L.A. Christensen, and D.L. Van Dyne. 1979. Animal waste utilization on cropland and pastureland: A manual for evaluating agronomic and environmental effects. USDA Utilization Res. Rep. no. 6. U.S. Gov. Print. Office, Washington, DC.

Hadas, A., and R. Portnoy. 1994. Nitrogen and carbon mineralization rates of composted manures incubated in soil. J. Environ. Qual. 23:1184-1189.

Johnson, C.M., and A. Ulrich. 1959. Analytical methods for use in plant analysis. Bull. 766. Univ. of California, Agric. Exp. Stn., Berkeley, CA.

Knudsen, D.R., R.B. Clark, J.L. Dening, and P.A. Pier. 1981. Plant analysis of trace elements by x-ray. J. Plant Nutr. 3:61-75.

Littell, R.C., G.A. Milliken, W.W. Stroup, and R.D. Wolfinger. 1996. SAS system for mixed models. SAS Institute, Cary, NC.

Magdoff, F.R., and J.F. Amadon. 1980. Yield trends and soil chemical changes resulting from $\mathrm{N}$ and manure application to continuous corn. Agron. J. 72:161-164.

Overcash, M.R., F.J. Humenik, and J.R. Miner. 1983. Livestock Waste Management. Vol. I. CRC Press, Boca Raton, FL.

Pratt, P.F., F.E. Broadbent, and J.P. Martin. 1973. Using organic wastes as nitrogen fertilizers. Calif. Agric. 27:10-13.

Schepers, J.S., D.D. Francis, and M.T. Thompson. 1989. Simultaneous determination of total $\mathrm{C}$, total $\mathrm{N}$, and ${ }^{15} \mathrm{~N}$ on soil and plant material. Commun. Soil Sci. Plant Anal. 20:949-959.

Schlegel, A.J. 1992. Effect of composted manure on soil chemical properties and nitrogen use by grain sorghum. J. Prod. Agric. 5:153157.

Schulten, H.R., and P. Leinweber. 1991. Influence of long-term fertilization with farmyard manure on soil organic matter: characteristics of particle-size fractions. Biol. Fertil. Soils 12:81-88.

Sommerfeldt, T.G., and C. Chang. 1985. Changes in soil properties under annual applications of feedlot manure and different tillage practices. Soil Sci. Soc. Am. J. 49:983-987.

USDA. 1997. Agricultural Statistics. U.S. Gov. Print. Office, Washington, DC

Vitosh, M.L., J.F. Davis, and B.D. Knezek. 1973. Long-term effects of manure, fertilizer, and plow depth on chemical properties of soil and nutrient movement in a monoculture corn system. J. Environ. Qual. 2:296-299. 